\title{
Shawi (Chayahuita)
}

\author{
Luis Miguel Rojas-Berscia \\ Radboud Universiteit Nijmegen, Centre for Language Studies \\ \& Max Planck Institute for Psycholinguistics, Language and Cognition Department \\ \& University of Queensland, School of Languages and Cultures \\ I.rojasberscia@uq.edu.au \\ Andrés Napuríi \\ University of Oxford, School of Anthropology and Museum Ethnography \\ \& Pontificia Universidad Católica del Perú, Departamento Académico de Humanidades \\ a.napuri@pucp.edu.pe \\ Lei Wang \\ Tongij University, School of Foreign Languages \\ \& Radboud Universiteit Nijmegen, Centre for Language Studies \\ w1410512@gmail.com
}

Shawi $^{1}$ is the language of the indigenous Shawi/Chayahuita people in Northwestern Amazonia, Peru. It belongs to the Kawapanan language family, together with its moribund sister language, Shiwilu. It is spoken by about 21,000 speakers (see Rojas-Berscia 2013) in the provinces of Alto Amazonas and Datem del Marañon in the region of Loreto and in the northern part of the region of San Martín, being one of the most vital languages in the country (see Figure 1). ${ }^{2}$ Although Shawi groups in the Upper Amazon were contacted by Jesuit missionaries during colonial times, the maintenance of their customs and language is striking. To date, most Shawi children are monolingual and have their first contact with Spanish at school. Yet, due to globalisation and the construction of highways by the Peruvian government, many Shawi villages are progressively westernising. This may result in the imminent loss of their indigenous culture and language.

As for documentation of Shawi, there was no single grammatical sketch of it until the 1980s, when the Christian missionary and SIL linguist Helen Hart initiated a project to study and describe the language. Hart, together with a large number of consultants coming from very different Shawi-speaking communities, translated the New Testament into Shawi (Hart 1978), wrote a very complete dictionary of the language (Hart 1988), as well as a short grammar sketch, and wrote the first phonological sketch of the language (Gordon de Powlison et al. 1976). More recently, Barraza de García (2005) wrote a Ph.D. dissertation on the verbal system of Shawi, and Luis Miguel Rojas-Berscia worked on the syntax and semantics of causative constructions (Rojas-Berscia 2013) and the distribution of split ergativity in the language (Rojas-Berscia \& Bourdeau 2018).

There were, however, a few substantial attempts to analyse the history of the language. One of these was Beuchat \& Rivet (1909), dedicated to the study of the origins of Kawapanan

\footnotetext{
${ }^{1}$ The audio files were recorded using a Zoom H6 Handy Recorder and a ME64 Sennheiser Cardioid microphone.

${ }^{2}$ The map also shows the area where Munichi, an isolate, is spoken. This language is of special importance since it has been in contact with Kawapanan languages before and after the settlement of the Spaniards in this region.
} 


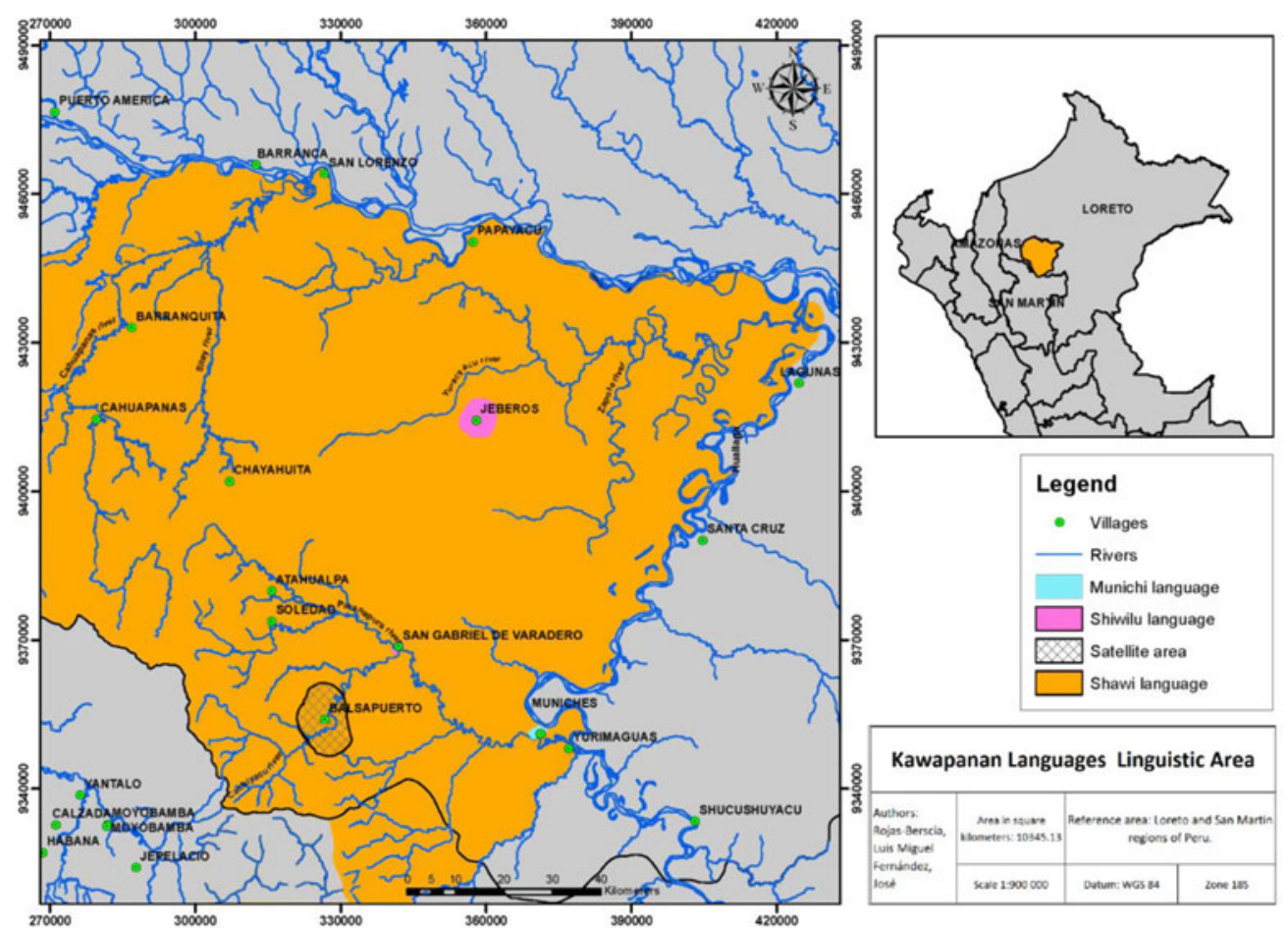

Figure 1 Map of the Kawapanan linguistic area.

languages, mentioning for the first time a clear cut between this language family and Chicham/Jivaroan. The number of comparative and philological studies of the Kawapanan languages increased exponentially during the last decade. Valenzuela (2011) worked extensively on the reconstruction of Proto-Kawapanan, as well as on possible areal connections with major Andean languages such as Quechua and Aymara (Valenzuela 2015). Thanks to current philological analyses of 18th-century Shiwilu (Alexander-Bakkerus 2013, 2016; Rojas-Berscia 2017), and to current descriptions of both Shawi and Shiwilu, we will be able to better understand the underlying dynamics behind the emergence of the great linguistic diversity found in Northwestern Amazonia.

\section{Consonants}

The Shawi phoneme inventory consists of twelve consonants and four vowels. The consonants phoneme group consists of five plosives, two fricatives, two nasals, one tap, and two approximants. The following consonant chart is adapted from Rojas-Berscia (2013: 23).

\begin{tabular}{|l|c|c|c|c|c|c|}
\hline & Bilabial & Alveolar & $\begin{array}{c}\text { Post- } \\
\text { alveolar }\end{array}$ & Palatal & Velar & Glottal \\
\hline Plosive & $\mathrm{p}$ & $\mathrm{t}$ & $\overparen{\mathrm{t}}$ & & $\mathrm{k}$ & $\mathrm{P}$ \\
\hline Fricative & & $\mathrm{s}$ & $\int$ & & & \\
\hline Nasal & $\mathrm{m}$ & $\mathrm{n}$ & & & & \\
\hline Tap & & $\mathrm{f}$ & & & & \\
\hline Approximant & $\mathrm{w}$ & & & $\mathrm{j}$ & & \\
\hline
\end{tabular}


Minimal pairs are offered below in phonemic transcriptions, with syllable boundaries indicated by dots and stress by [']. The list was kept as minimal as possible. Some consonants are repeated to illustrate contrastiveness as accurately as possible. The words are followed by their orthographic representations and English glosses. (Abbreviations used in this paper are listed at the end of the transcription section.)

\begin{tabular}{|c|c|c|c|c|c|c|c|c|}
\hline $\mathbf{p} / \mathbf{t} / \mathbf{k}$ & & & $\mathbf{n} / \mathbf{f}$ & & & $\mathrm{n} / \mathbf{P}$ & & \\
\hline 'par.a & $p a^{\prime} a$ & 'go IMP' & 'na.ni & nani & 'already' & 'na1.pi.rin & na'apirin & 'hide' \\
\hline 'ka?.a & $k a^{\prime} a$ & 'eat IMP' & na.'ri & nari & 'it is a & 'nan.pi.rin & nanpirin & 'live' \\
\hline 'ta?.a & ta'a & 'run IMP' & & & joke’' & & & \\
\hline $\mathbf{s} / \int$ & & & $\mathbf{j} / \mathbf{w}$ & & & & & \\
\hline 'sa.wi & sawi & 'type of & 'ja.nan & yanan & 'piraña' & & & \\
\hline & & palm tree' & 'wa.nan & wanan & 'long tree' & & & \\
\hline 'Sa.wi & Shawi & ‘Shawi' & & & & & & \\
\hline 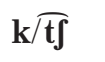 & & & $\mathbf{m} / \mathbf{n}$ & & & & & \\
\hline ki & $i k i$ & 'pain' & 'na.nan & nanan & 'language' & & & \\
\hline$\overparen{t T i-}$ & & SOC.CAUS & 'na.man & naman & 'peccary' & & & \\
\hline
\end{tabular}

Unlike Barraza de García (2005: 37), we do not include the segment $\left.{ }^{\mathrm{h}}\right]$ as a phoneme of the language. As already noted by Hart (1988) - evident from her transcriptions and previous analyses of the phonology of the language (Gordon de Powlison et al. 1976) $-\left[{ }^{\mathrm{h}}\right]$ is not phonemic, as will be shown in the 'Processes' section.

\section{Plosives}

There are five plosives in Shawi. On the basis of proprioceptive and visual observations, /p/ is an unaspirated bilabial plosive, / $\mathrm{t} /$ is a laminal alveolar plosive, and $/ \mathrm{k} /$ is a dorsal velar plosive. All of them occur in onset position. None of these plosives are allowed in coda position. Below we present some examples:

$/ \mathrm{p} /$

'par.pi 'very'

$/ \mathrm{t} /$

ni.'to.ton 'intelligent'

'ta.jii 'night'

$/ \mathrm{k} /$

kan.'pi.ta 2PL

ni.'ka.na.on 'I give a present' 
$\widetilde{\mathrm{t} f} /$ occurs at the beginning of the word, as in the word ' $\mathrm{t}$ i.mi.naw 'I die'. $\overparen{\mathrm{tg}} /$ is a laminal postalveolar affricate. The occurrence of this consonant inside the word or root is rare, but possible. Below we present some cases:

i. $\overparen{t j i-}$ SOC.CAUS

'Tिan. $\overline{t \int o n}$ 'bad spirit'

o. 'T 'thick vine with large thorns'

Some borrowings which present the prototypical $/ \mathrm{d}_{3} /$ of Amazonian Spanish are accommodated to $\overparen{\mathrm{tg}} /$ in the language, such as the word for 'street', kachi ['ka.t Tii] (Spanish 'calle').

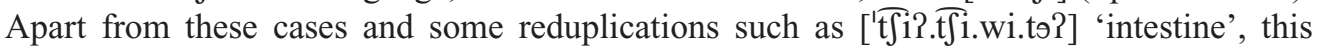
phoneme is very productive in front of $/ \mathrm{i} /$, but not with the other vowels, which suggests a diachronic palatalisation process from $* \mathrm{ki} / \mathrm{ti}>\left[\widehat{\mathrm{t} \int \mathrm{i}}\right]^{3}$

The glottal stop in Shawi does not behave like most Shawi consonants: it only occupies the coda position:

'par.pi 'very'
'na?.a 'many'
'sa?.a 'wife'

Plosives can undergo inter-vocalic voicing. This phenomenon occurs mostly in southern varieties:

/pa?.sa.pon/ > [pa?.sa.won] 'I will be going'

In this case, $/ \mathrm{p} /$ underwent voicing and was realised as its allophone [b]. Nevertheless, in most southern varieties of Shawi, [b] is realised as [w] due to lenition. This process is progressively leading to the elision of the consonant. Below we present one of the most prototypical examples:

/sa.na.pi/ > [sa.na.wi] $>$ [sa.na.i] 'woman'

Voicing after nasals also occurs in Shawi, as well as in Shiwilu (see Valenzuela \& Gussenhoven 2013, Madalengoitia 2013). This phenomenon, however, is absent in southern varieties such as the Paranapura variety. Barraza de García (2005: 49) documents the occurrence of this phenomenon in Cahuapanas and Sillay Shawi. ${ }^{4}$ For example:

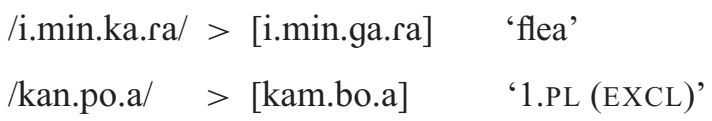

${ }^{3}$ Colonial evidence for this phenomenon can be found in Beuchat \& Rivet (1909) who document timin- for the verb 'to die', as in modern Shawi chiminaw 'I die'. We can infere, therefore, that Proto-Kawapanan *t palatalised. Other consonants, such as * $k$, palatalised as well. A more detailed discussion can be found in Rojas-Berscia \& Nikulin (2018).

${ }^{4}$ This phenomenon is also documented in Southern Mayna, the possible ancestor of Modern Shawi (RojasBerscia 2015). 


\section{Fricatives}

There are two fricatives in Shawi. /s/ is a laminal alveolar fricative, while $/ \mathrm{S} /$ is a laminal post-alveolar fricative. Like the plosives, both occur in onset position, never in coda position.

/s/

'nan.sa 'to dance'

'sa.ka 'to work'

$/ \int /$

'Sa?.wi 'to tell'

a.'ma.ja 'a bit'

'Son.ka 'ten'

Fricatives can also undergo voicing. This phenomenon occurs mostly in southern varieties, e.g.:

$/$ ka.so/ > [ka.zo] 'I (EMPHATIC)'

\section{Nasals}

There are two nasal consonants in Shawi. $/ \mathrm{m} /$ is a bilabial nasal, while $/ \mathrm{n} /$ is a laminal alveolar nasal. Both occur in onset position. $/ \mathrm{n} / \mathrm{can}$ occur in coda position.

$/ \mathrm{m} /$

'ma. So 'old man'

'a.ma PROHIB

$/ \mathrm{n} /$

'na.ra? 'tree'

'Wэ.ron 'seed'

'sa.na.pi 'woman'

Nasals assimilate in place to a following consonant. Below we present some examples. In some cases, however, nasals coalesce with the preceeding vowel, which becomes nasalised. This is explained in the section on vowels.

$$
\begin{aligned}
& \text { /kon.pa.na.ma?/ > [kom.pa.na.ma?] 'Cumpanamá' } \\
& \text { /kan.kan/ > [kay.kay] 'wasp' }
\end{aligned}
$$

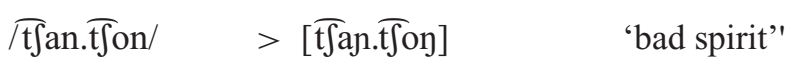

As shown in the last two words, the nasal /n/ is realised as its velar allophone [ $\mathrm{y}]$ in coda position. 
Tap

In Shawi there is only a single tap - the apical alveolar $/ \mathrm{r} /$. As most consonant phonemes in the language, it only occurs at the beginning of the syllable, e.g.:

$\begin{array}{ll}\text { 'i.ra } & \text { 'path' } \\ \text { 'na.ra? } & \text { 'tree' } \\ \text { 'wa.ro } & \text { 'turkey' } \\ \text { ka.'ri'5 } & \text { 'I (ERG)' }\end{array}$

$/ \mathrm{r} /$ is neutralised in word-initial onsets and, word-internally, after a glottal stop. Once neutralisation takes place, $/ \mathrm{r} /$ is realised as [n]. Consequently, the occurrence of [ $\mathrm{r}]$ as onset of the first syllable is almost ${ }^{6}$ inexistent. $^{7}$ Examples include:

$\begin{array}{ll}\text { 'ar.na } & \text { 'one' } \\ \text { 'nor.pa 'ground' }\end{array}$

\section{Approximants}

Shawi is characterised by a frequent occurrence of approximants, just like its sister language Shiwilu (Valenzuela \& Gussenhoven 2013: 100). Approximants behave very much like their other consonantal counterparts. They always occur in onset position and never in coda position. $/ \mathrm{w} /$ is a labial-velar approximant. $/ \mathrm{j} /$ is a palatal approximant. Below we present some examples:
/w/
wa.'ran.ka 'thousand'
i?.'wa.ra 'yesterday'
/j/
'ki.ja 1PL.EXCL

However, they cannot occur in onset position when a vowel of a similar articulation follows: $/ \mathrm{w} /$ never occurs before $/ \mathrm{o} /$, and $/ \mathrm{j} /$ never occurs before $/ \mathrm{i} /$.

\section{Vowels}

Shawi has four vowels: the close front unrounded /i/, the close-mid central unrounded /s/, the open central /a/ and the close-mid back rounded /o/. A similar analysis can be found in Gordon de Powlison et al. (1976). Vowels occur in every word context and there is no clear synchronic quantity contrast. ${ }^{8}$ The vowel chart for Shawi, including its main vocalic features, is adapted from Rojas-Berscia (2013: 30).

\footnotetext{
${ }^{5}$ We are not marking the primary stress in this word because of its complex morphosyntactic nature. More on this phenomenon can be found in the section on metrical stress.

${ }^{6}$ (Hart 1988: 198) registers the word ropatërin [ru.pa.ti.rin] 'to tremble/shiver'. However, it is absent in our corpus.

${ }^{7}$ The Proto-Kawapanan phoneme */1/ became Shawi $[\mathrm{n}]$ in onset position at the beginning of words, and $[\mathrm{r}]$ in word-internal onsets (see Rojas-Berscia \& Nikulin 2018).

${ }^{8}$ However, quantity constrast can be marginally observed in some words, as observed by Gordon de Powlison et al. (1976). This awaits further investigation.
} 


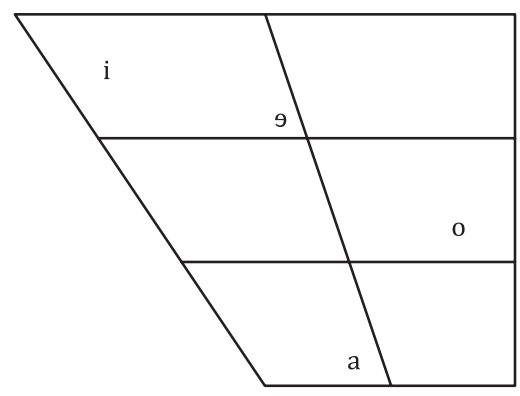

Minimal pairs are offered as phonemic transcriptions with syllable boundaries indicated by dots and stress by [']. Some vowels are repeated to illustrate contrastiveness as accurately as possible.

\begin{tabular}{|c|c|c|c|c|c|c|c|c|}
\hline $\mathbf{a} / \mathbf{i}$ & & & $a / 9$ & & & $\mathrm{i} / \mathrm{e}$ & & \\
\hline na.'to? & nate' & 'tooth' & 'ta.ms & tame & 'vulture' & 'ง?. & $e^{\prime}$ sha & 'anona' \\
\hline $\begin{array}{l}\text { i..'to? } \\
\mathbf{a} \mathbf{u}\end{array}$ & nite' & 'nose' & $\begin{array}{l}\text { 'tэ.m९ } \\
\mathbf{i} / \mathbf{u}\end{array}$ & teme & 'louse' & $\begin{array}{l}\text { 'ip. } \int a \\
\text { u/9 }\end{array}$ & $i^{\prime} s h a$ & 'water' \\
\hline $\begin{array}{l}\text { 1. } \int \mathrm{a} ? \\
\mathrm{a} \cdot \int \mathrm{a}\end{array}$ & $\begin{array}{l}\text { nusha' } \\
\text { nasha }\end{array}$ & $\begin{array}{l}\text { 'meat' } \\
\text { 'new' }\end{array}$ & $\begin{array}{l}\text { 'na.nu } \\
\text { 'na.ni }\end{array}$ & $\begin{array}{l}\text { nanu } \\
\text { nani }\end{array}$ & $\begin{array}{l}\text { 'young lady' } \\
\text { 'already' }\end{array}$ & $\begin{array}{l}\text { 'to.nэ } \\
\text { 'to.nu }\end{array}$ & $\begin{array}{l}\text { tene } \\
\text { tenu }\end{array}$ & $\begin{array}{l}\text { 'penis' } \\
\text { 'leaves' }\end{array}$ \\
\hline
\end{tabular}

Below we provide an acoustic analysis, carried out with the help of a male consultant of Pueblo Chayahuita. The analysis is based on 16 words from a Swadesh list. The words used were: $k a$ 'I', a'na 'one', sami 'fish', and nante' 'foot' for /a/; pi' $i$ 'sun', ira 'path', iwan 'wind' inchinan 'left' for /i/; werun 'leaf', pen 'fire', teme 'louse', and kema 'you' for / $/ \mathrm{s}$; and nu'pa 'soil', shu'shu 'nipple', nuya 'good', and ku 'no' for /o/. Table 1 displays the means of F1 and F2 for each of the vowels in the four words:

Table 1 Means of F1 and F2 after four words.

\begin{tabular}{lcc}
\hline & $F 1$ & $F 2$ \\
\hline /a/ & 718.16 & 1519.05 \\
/i/ & 329.86 & 2354.86 \\
/与/ & 422.71 & 1952.96 \\
/o/ & 448.00 & 1066.39 \\
\hline
\end{tabular}

The IPA symbol used for each token is based on vowel quality and our familiarity with the sounds. The distribution of vowel sounds in the plot is presented in Figure 2 (on next page).

There are no nasal vowels in the language. However, Shawi vowels sometimes become nasalised when followed by a nasal, while the nasal itself is deleted. This occurs only in word-final position. ${ }^{9}$ Below we present some examples:

$\begin{array}{lll}\text { /sa.po.rin/ } & >\text { [sa.po.rĩ }] & \text { 'he has fever' } \\ \text { /jon.ka.tan/ } & >\text { [jon.ka.tã }] & \text { 'you swim' } \\ \text { /na?.kon/ } & >\text { [na?.kõ }] & \text { 'many' } \\ \text { /ka.kən/ } & >\left[\mathrm{ka}^{\mathrm{h}} \cdot \mathrm{k} \text { õ }\right] & \text { 'mine' }\end{array}$
${ }^{9}$ It must be noted that this is subject to variation. There is no categorical nasalisation of vowels before
word-final nasals. This is a topic which awaits further research. 


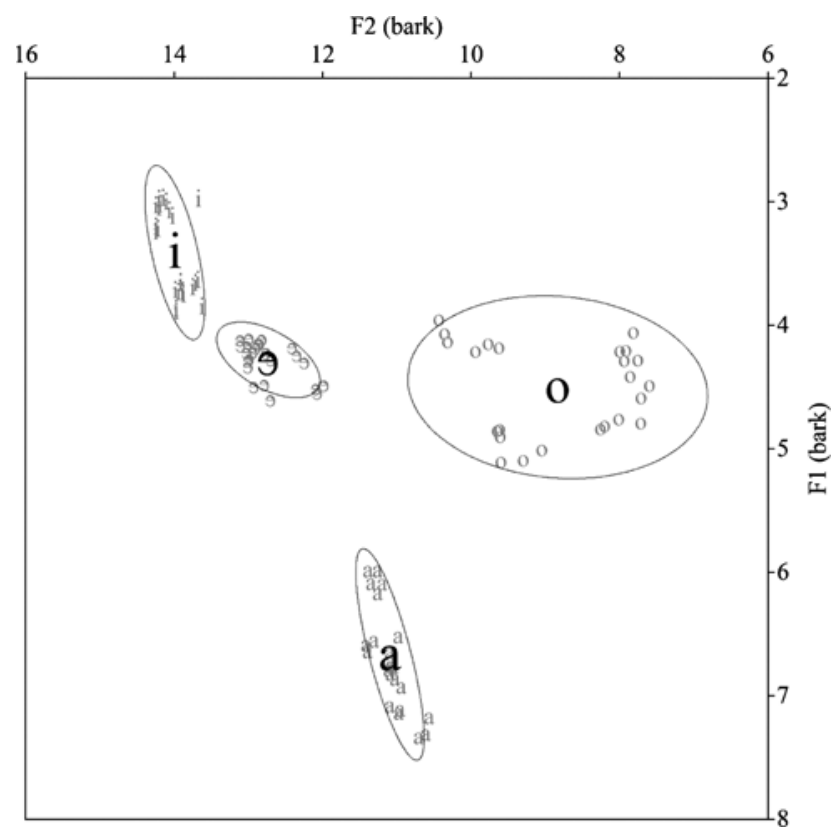

Figure 2 Vowel ellipses for $/$ i s o a/ in the F1/F2 plane. Each vowel contains 24 scatters ( 4 words $\times 2$ repetitions $\times 3$ equidistant measurements taken from the steady-state portion). Raw formant values were converted to bark and sigma ellipses were superimposed (number of sigmas $=2$ ) in Praat (Boersma \& Weenink 2016).

\section{Syllable structure}

The general syllable structure of the language is $(\mathrm{C}) \mathrm{V}(\mathrm{C}[+$ nasal, + dorsal $] /[+$ contr gl] $)$, with both the onset and the coda being optional. CC-onsets are normally the product of reductions, such as the VM+NON.FUT construction te-ra>tra-, and the 1.INCL marker, $p u-w a>-p w a$.

A detailed overview of the distribution and restrictions of occurrence of consonantal phonemes in syllable structure is presented in Table 2.

Table 2 Distribution of consonantal phonemes. $(Y)$ indicates a consonant occurs in position $(X)$ while $(\mathbb{N})$ indicates that it does not. (-) indicates that, although that combination is possible, such a syllable does not appear in the corpus. \#_ = word-initial;. _ I = syllable-initial, V._= post-vocalic; $C_{-}{ }_{-}=$post-consonantal; _. = syllable final, _\# = word-final; _ $(\mathrm{X})=$ preceding vowel $(\mathrm{X})$. $/ \mathrm{p} \mathrm{t} \mathrm{k} \mathrm{t \int} \mathrm{s} \mathrm{S} /$ constitute a natural class in the language.

\begin{tabular}{|c|c|c|c|c|c|c|c|c|c|c|c|}
\hline Phoneme & $\#_{-}$ & - & V._ & $\mathrm{n}_{-}$ & ?. & - & _\# & _a & _9 & _i & _o \\
\hline$/ \mathrm{p} /$ & $Y$ & $Y$ & $Y$ & $Y$ & $Y$ & $N$ & N & $Y$ & $Y$ & $Y$ & $Y$ \\
\hline$/ \mathrm{t} /$ & Y & y & Y & Y & Y & N & N & Y & Y & Y & Y \\
\hline$/ \mathrm{k} /$ & Y & Y & Y & Y & Y & $\mathrm{N}$ & N & Y & Y & Y & Y \\
\hline $\mid \mathrm{tg} /$ & Y & Y & Y & Y & Y & N & N & Y & - & Y & Y \\
\hline$/ \mathrm{s} /$ & Y & Y & Y & y & Y & N & N & Y & Y & Y & Y \\
\hline$/ \mathrm{J} /$ & Y & Y & Y & Y & Y & $N$ & N & Y & Y & Y & Y \\
\hline$/ \mathrm{m} /$ & $Y$ & $Y$ & $Y$ & $\mathrm{~N}$ & $Y$ & $\mathrm{~N}$ & $\mathrm{~N}$ & $Y$ & $Y$ & $Y$ & $Y$ \\
\hline$/ \mathrm{n} /$ & Y & Y & Y & N & Y & Y & Y & Y & Y & Y & Y \\
\hline$/ \mathrm{r} /$ & $Y$ & $Y$ & $Y$ & $\mathrm{~N}$ & $Y$ & $\mathrm{~N}$ & $\mathrm{~N}$ & $Y$ & $Y$ & $Y$ & $Y$ \\
\hline$/ \mathrm{w} /$ & $Y$ & $Y$ & $Y$ & $\mathrm{~N}$ & $Y$ & $\mathrm{~N}$ & $\mathrm{~N}$ & $Y$ & $Y$ & $Y$ & $\mathrm{~N}$ \\
\hline$/ \mathrm{j} /$ & Y & Y & Y & N & Y & N & N & Y & $Y$ & N & Y \\
\hline$/ 2 /$ & $\mathrm{N}$ & $\mathrm{N}$ & $Y$ & $\mathrm{~N}$ & $\mathrm{~N}$ & $Y$ & $Y$ & $\mathrm{~N}$ & $\mathrm{~N}$ & $\mathrm{~N}$ & $\mathrm{~N}$ \\
\hline
\end{tabular}




\section{Processes}

${ }^{\mathrm{h}}$ ] epenthesis in coda position

Shawi displays an [h]-like segment in some words. Figures 3 and 4 show the spectrograms of two words, kema 'you' and keken 'heavy', respectively. The former does not display [h]. The latter shows a friction in the coda position of the first syllable.

The occurrence of $\left[{ }^{\mathrm{h}}\right]$ was previously described as a co-vowel by Gordon de Powlison et al. (1976:2), and as an independent phoneme of the language by Barraza de García (2005). Both accounts agree upon the fact that $[\mathrm{h}]$ only occurs in coda position. Yet, the occurrence of $[\mathrm{h}]$ can be explained in terms of a simple lexical rule of epenthesis (Gussenhoven \& Jacobs 2011: 164). Epenthesis is expressed as insertion of $\left[{ }^{\mathrm{h}}\right]$ in coda position. This is a rule specified in the lexicon. Thus, the rule only applies before any derivational or inflectional processes have taken place. $\left[{ }^{\mathrm{h}}\right]$ is then inserted as a coda to an open syllable if the onset of the following syllable is an obstruent (plosives and fricatives). All these conditions must be met in order for $\left.{ }^{[}\right]$to occur. The fact that $[\mathrm{h}]$ only occurs before an obstruent resembles the phonetic environment required in Huariapano (Parker 1994: 108-109) for the $\left.{ }^{\mathrm{h}}\right]$ epenthesis.
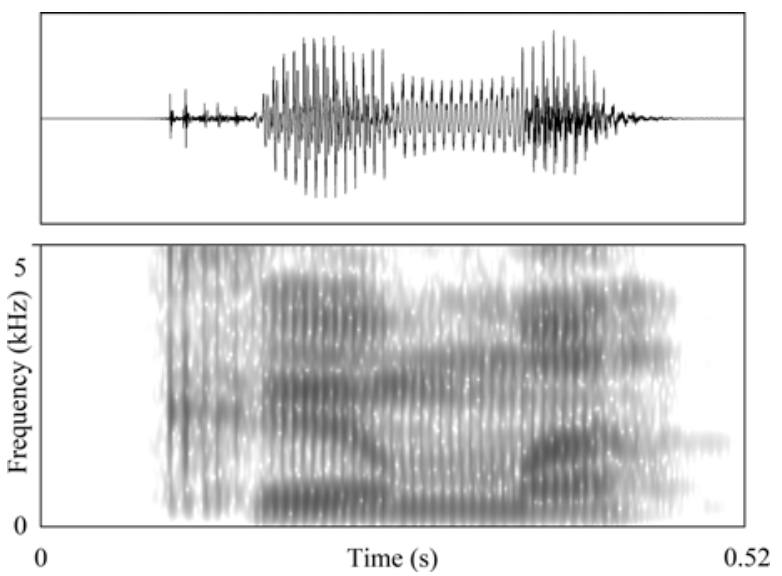

Figure 3 Spectrographic representation of /kэma/ 'you'. In this case no $\left.{ }^{\mathrm{h}}\right]$ is found.

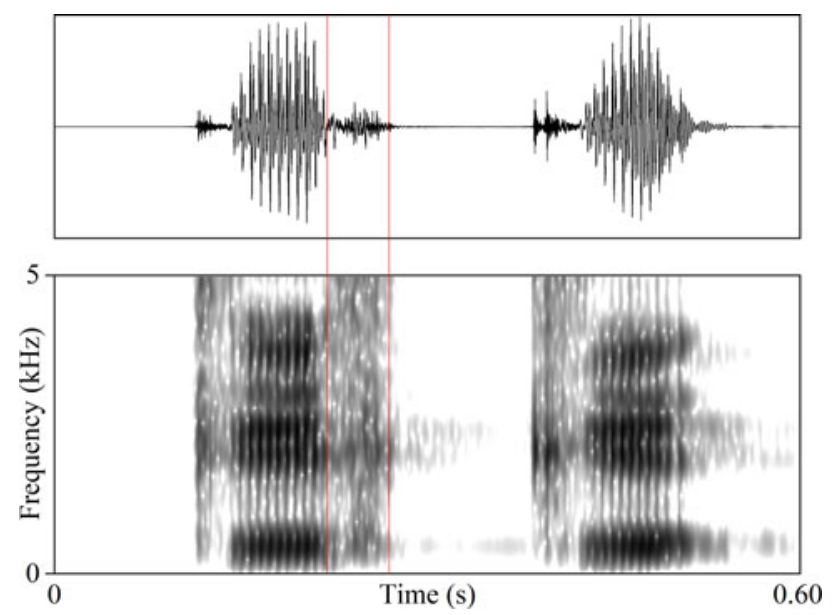

Figure 4 Spectrographic representation of /køkøn/ 'heavy'. The friction found in the coda of the first syllable has been marked. 
Below we present some examples, including the underlying form as specified in the lexicon, followed by the form which already underwent $\left[{ }^{\mathrm{h}}\right]$ epenthesis. Some derivational or inflectional processes were specified as occurring postlexically:

\begin{tabular}{|c|c|c|c|}
\hline UNDERLYING & {$[\mathrm{h}]$ EPENTHESIS } & DERIVATION/INFLECTION & MEANING \\
\hline jo.ki & ${ }^{\prime} \mathrm{jo}^{\mathrm{h}} \cdot \mathrm{ki}$ & & 'moon’ \\
\hline ta. $\int \mathrm{i}$ & $\operatorname{ta}^{\mathrm{h}} \cdot \int \mathrm{i}$ & & 'night' \\
\hline So. So & ${ }^{\prime} \int o^{h} \cdot \int o$ & & 'ring-tailed coati' \\
\hline pa.sa & 'pa ${ }^{\mathrm{h}} . \mathrm{sa}$ & & 'bruise' \\
\hline i.sa & ${ }^{\prime} i^{h} . s a$ & & 'fruit' \\
\hline pi.ta & 'pi ${ }^{\mathrm{h}} . \mathrm{ta}$ & 'pi ${ }^{\mathrm{h}} . \mathrm{ta}+\mathrm{raw}[1 \mathrm{PL}]$ & '(I) push’ \\
\hline tfi.to & 't t $\mathrm{i}^{\mathrm{h}}$.to.ro & 't $\mathrm{g} \mathrm{i}^{\mathrm{h}} . \mathrm{to}+\mathrm{ro}[\mathrm{CLF}]$ & 'cloud' \\
\hline na.po.ro.i & ${ }^{\prime}$ na ${ }^{h}$.po.ro.i & & 'long' \\
\hline tэ.pa & 'tg ${ }^{\mathrm{h}} \cdot \mathrm{pa}$ & $n i+{ }^{\prime}{ }^{h}{ }^{h} \cdot p a+w$ & 'I will kill myself' \\
\hline
\end{tabular}

All examples meet all conditions. Nitepaw $\left[\mathrm{ni}^{+}{ }^{\mathrm{t}} \mathrm{g}^{\mathrm{h}} \cdot \mathrm{pa}+\mathrm{w}\right]$ is of special interest. Had the rule not applied at the lexical level, the outcome would have been $*\left[\mathrm{ni}^{\mathrm{h}}{ }^{\text {' }} \mathrm{tg}^{\mathrm{h}} \cdot\right.$.paw]. The rule, nevertheless, applied before the prefixation of $n i$ - 'reciprocal'.

There are some suffixes, such as the progressive $-s a$, the genitive -ken and the additive $-p u$, which also trigger the occurrence of $\left[{ }^{\mathrm{h}}\right]$ outside the main lexical rule. ${ }^{10}$ The suffixes $-p u$ and -ken trigger the occurrence of $\left[{ }^{\mathrm{h}}\right]$ in the preceding syllable. By contrast, -sa triggers the occurrence of $\left[{ }^{\mathrm{h}}\right]$ in the following syllable. Although the rule applies postlexically, the syllable in question must be open. This area of morphophonemics, however, still awaits further exploration. Below we present some examples (bold indicates the place of these suffixes in the examples):

[a?.na.to.'ra ${ }^{\mathrm{h}}$.po] 'five (lit. and one hand)'

[kэ.'ma $\left.{ }^{\mathrm{h}} \cdot \mathbf{p o}\right] \quad$ 'and you'

$\left[{ }^{\prime} \mathrm{ka}^{\mathrm{h}} \cdot \mathbf{k} \tilde{\jmath}\right] \quad$ 'mine'

[ta.Pa.'za' ${ }^{\text {h }}$.pi] 'they are running'

\section{Syncope}

Syncope is frequent in Shawi speech. There are two suffixes that are commonly syncopied: -we 1.SG and -te VM. Examples include the following:

/nan.sa.ra.wg/ > [nan.sa.raw] 'I dance'

/pa?.sa.ra.ws/ > [pa?.sa.raw] 'I am going'

/Sa?.wi.to.ra.ws/ > [ [a?.wi.traw] 'I tell something to somebody'

\footnotetext{
${ }^{10}$ There is one single exception to the rule, the verb $n i h$ - 'to be', which requires $\left.{ }^{\mathrm{h}}\right]$.
} 


\section{Transcription of the recorded passage}

The story of the North Wind and the Sun was translated from its original English version in one session with the help of speaker A. The transcription is phonemic. Parentheses indicate intonational phrases.

\section{Phonemic transcription}

This is a broad transcription, which exclusively employs segmental symbols that were assigned to vocalic and consonantal phonemes.

('i.wan) ('pir.i.'pi.pi.rin.'kэ.ran) (i.'nawa) ('pi?.i) ('ja.wa.pi.ri.na.wo) ('in.ta) ('t

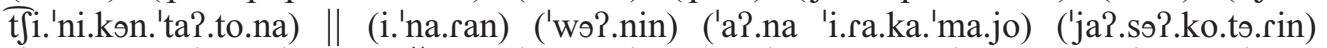
('a2.na) (wo.'to.ja 'ko.ton) || (i.na.'pi.ta) ('kan.pi) ('a2.na) (jon.'ki.nan.kэ) ('in.ta) ('i.na) ('i.ra.ka.'ma.jo) ('ko.ton) ('ma?.to.rin.so) ('i.na) ('ni.sa.rin) ('tfi.ni t tji.'ni.kэn.'to.pi)

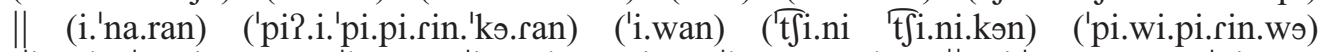
('i.ra.ka.'ma.jo.so) (a.'kэ.to) ('ja.so.ko.to.rin) ('ko.to.nэn.kэ) \| (i.'na.ran) (to.'pi.nan) ('i.wan) ('pi?.i.'pi.pi.rin.kэ.ran) (ka.'no.to.rin) \| (i.'na.ran) ('pii.i) ('a2.pi.nin) ('wo.no.ka?) | (i.'na.ran) ('na.po.a.wa.ton) ('i.ra.ka.'ma.jo) ('ko.ton) ('i.nan.pi.ra.rin) || (i.'na.po. $\widehat{t j i n)}$

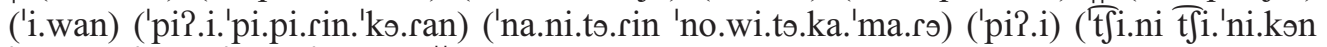
'ni.ton) ('ka.to.'ro.sa.'kэ.ran) \|

\section{Orthographic version}

This is an orthographic version, in the current official Shawi alphabet, as requested by our consultants.

Iwan pi'ipihpirinkeran inawa Pi'i yawapirinawe inta chini chinihken ta'tuna. Inaran we'nin a'na irakamayu yase'kuterin a'na wehtuya kuhtun. Inapita kampi a'na yunkinanke inta ina irahkamayu kuhtun ma'terinsu ina nihsarin chini chinihken tuhpi. Inaran pi'ipihpirinkeran Iwan chini chinihken piwipirinwe irahkamayu ahkete yasekuterin kuhtunenke. Inaran tuhpinan Iwan pi'ipihpirinkeran kanuhterin. Inaran Pi'i a'pini wenuka', inaran nahpuawatun irakamayu kuhtun inanpirarin. Inahpuchin Iwan pi'ipihpirinkeran naniterin nuwitekamare Pi'i chini chinihken nihtun kahturusakeran.

\section{Glossed and translated version}

Iwan pi'i-pihpi-r-in-ke-ran inawa Pi'i yawa-pi-r-in-na-we

wind sun-exit-NON.FUT-3-LOC-ABL and sun fight-FRUST-NON.FUT-3-PL-NEG

in-ta chini chinih-ken-t-atu-na.

who-INT strong strong-ADJTZ-VM-SEQ-3.PL

'The North Wind and the Sun were discussing on who the strongest among them was.'

Ina-ran we'-n-in a'na ira-kamayu' ya'se-ku-te-r-in a'na

3-ABL come-NON.FUT-3 one path-expert grab-ANDAT?-VM-NON.FUT-3 one

wehtuya kuhtun.

warm shirt

'A hermit came by, wearing heavy clothes.' 
Ina-pita kam-pia'na yunkinan-ke in-ta' ina irah-kamayu kuhtun 3-PL order-3.PL one idea-LOC who-INT 3 path-expert shirt ma'-te-r-in-su' ina nih-sa-r-in chini chinih-ken-tuh-pi. put-VM-NON.FUT-3-NMLZ 3 be-PROG-NON.FUT-3 strong strong-ADJTZ-VM-3.PL 'They decided that whoever caused the hermit to lose his shirt would be the strongest.'

Ina-ran pi'i-pihpi-r-in-ke-ran Iwan chini chinih-ken

3-ABL sun-exit-NON.FUT-3-LOC-ABL wind strong strong-ADJTZ piwi-pi-r-in-we irah-kamayu ahkete ya'se-ku-te-r-in blow-FRUST-NON.FUT-3-NEG path-expert more grab-ANDAT-VM-NON.FUT-3 kuhtun-ne-n-ke. shirt-ALIEN-3-LOC

'Then, the North Wind blew strongly unsuccessfully. The hermit just kept hold of his shirt even more.'

Ina-ran tuhpinan Iwan pi'i-pihpi-r-in-ke-ran kanuh-te-r-in.

3-ABL just wind sun-exit-NON.FUT-3-LOC-ABL tired-VM-NON.FUT-3

'The North Wind surrendered.'

Ina-ran Pi'i a'pi-n-in wenuka', ina-ran nahpuawatun

3-ABL sun start-NON.FUT-3 warmth 3-ABL therefore

ira-kamayu kuhtun inanpi-ra-r-in.

path-expert shirt get.naked-PROG-NON.FUT-3

'Not long after that, the sun shone warmly. The hermit took off his shirt.'

\begin{tabular}{|c|c|c|}
\hline Inah-puchin & Iwan & pi'i-pihpi-r-in-ke-ran \\
\hline 3-СОМР & wind & sun-exit-NON.FUT-3-LOC-ABL \\
\hline nuwi-te-ka-mare & Pi'i chini & chinih-ken \\
\hline know-VM-PURP-BEN & strong & strong-ADJTZ because \\
\hline
\end{tabular}

'Therefore, the North Wind acknowledged that the Sun was the strongest of them both.' 


\section{ABBREVIATIONS}

The abbreviations used in this Illustration rely primarily on the Leipzig Glossing Rules.

$1,2,3$ first, second, third person

$\begin{array}{ll}\text { ABL } & \text { ablative } \\ \text { ADJTZ } & \text { adjectiviser } \\ \text { ALIEN } & \text { alienable } \\ \text { ANDAT } & \text { andative } \\ \text { BEN } & \text { benefactive } \\ \text { CLF } & \text { classifier } \\ \text { COMP } & \text { comparative } \\ \text { ERG } & \text { ergative } \\ \text { EXCL } & \text { exclusive } \\ \text { FRUST } & \text { frustrative } \\ \text { IMP } & \text { imperative }\end{array}$

$\begin{array}{ll}\text { INCL } & \text { inclusive } \\ \text { INT } & \text { interrogative } \\ \text { LOC } & \text { locative } \\ \text { NEG } & \text { negative } \\ \text { NON.FUT } & \text { non-future } \\ \text { PL } & \text { plural } \\ \text { PROG } & \text { progressive } \\ \text { PROHIB } & \text { prohibitive } \\ \text { PURP } & \text { purposive } \\ \text { SEQ } & \text { sequential } \\ \text { SOC.CAUS } & \text { sociative causative } \\ \text { VM } & \text { valency modifier }\end{array}$

\section{Acknowledgements}

We are grateful to Amalia Arvaniti and two anonymous referees for the insightful comments on a previous version of this Illustration. We also thank André Radtke for his help with the optimisation of the audio files. The first author acknowledges the financial and academic support from the Language in Interaction Research Consortium in the Netherlands. The authors greatly acknowledge the useful comments and criticisms on previous drafts of the present Illustration by Carlos Gussenhoven, Pieter Muysken, Steve Levinson, Pieter Seuren, Hamed Rahmani, Gunter Senft, Simeon Floyd, and Roberto Zariquiey. The first author is grateful to Pilar Valenzuela for the initial encouragement to study Kawapanan languages, as well as for her insighful comments during the Amazonicas VI conference in Leticia, Colombia, and Tabatinga, Brazil, in May 2016.

\section{Supplementary material}

To view supplementary material for this article, please visit https://doi.org/10.1017/S0025100 318000415.

\section{References}

Alexander-Bakkerus, Astrid. 2013. Vocabulario enla lengua castellano, la del ynga y xebera [Vocabulary in the Castilian, Inga and Xebera languages]. STUF - Language Typology and Universals 66(3), 229-256.

Alexander-Bakkerus, Astrid. 2016. Eighteenth Century Xebero: Mss. Add. 25,323 and 25,324 of The British Library, London (LINCOM Studies in Native American Linguistics 77). München: LINCOM.

Barraza de García, Yris Julia. 2005. El sistema verbal en la lengua shawi [The verbal system in the Shawi language]. Ph.D. thesis, Federal University of Pernambuco.

Beuchat, Henri \& Paul Rivet. 1909. La famille linguistique Cahuapana [The Kawapanan language family]. Zeitschrift für Ethnologie 41, 616-634.

Boersma, Paul \& David Weenink. 2016. Praat: Doing phonetics by computer [computer program]. Version 6.0.16. http://www. praat.org/ (5 April 2016). 
Gordon de Powlison, Esther, Helen Hart \& George Hart. 1976. La fonología del chayahuita [The phonology of Shawi]. Datos Etno-Lingüisticos: Colección de los archivos del ILV 28 [Collection of the archives of the Summer Institute of LInguistics], Lima-Summer Institute of Linguistics. Lima: Instituto Lingüístico de Verano.

Gussenhoven, Carlos \& Haike Jacobs. 2011. Understanding phonology, 3rd edn. London: Hodder.

Hart, Helen. 1978. El Nuevo Testamento de nuestro señor Jesucristo [The New Testament of our Lord Jesus Christ]. Orlando, FL: Wycliffe Bible Translator.

Hart, Helen. 1988. Diccionario Chayahuita-Castellano Castellano-Chayahuita, Canponanquë Nisha Nisha Nonacaso [Shawi-Spanish and Spanish-Shawi dictionary, to say many things in our language]. Lima: Summer Institute of Linguistics.

Madalengoitia, María Gracia. 2013. Bosquejo fonológico de la lengua jebero (shiwilu) [Phonological sketch of the Shiwilu language (Kawapanan)]. BA thesis, Pontificia Universidad Católica del Perú, Lima.

Parker, Steve. 1994. Coda epenthesis in Huariapano. International Journal of American Linguistics 60(2), 95-119.

Rojas-Berscia, Luis Miguel. 2013. La sintaxis y semántica de las construcciones causativas en el chayahuita balsaportino [The syntax and semantics of causative constructions in the Shawi language as spoken in Balsapuerto]. BA thesis, Pontifical Catholic University of Peru, Lima.

Rojas-Berscia, Luis Miguel. 2015. Mayna: The lost Kawapanan language. LIAMES: Linguas Indigenas Americanas 15, 393-407.

Rojas-Berscia, Luis Miguel. 2017. Review of Samuel Fritz (?), El vocabulario de la lengua xebera, una doctrina cristiana en xebero y quechua, y la gramática de la lengua xebera (siglo XVIII) [The vocabulary of the Xebero language, a Christian doctrine in Xebero and Quechua, and the gramar of the Xebero language (18th century)], edited by Astrid Alexander-Bakkerus. Madrid \& Frankfurt am Main: Iberoamericana Vervuert (2016). Lexis (Peru) 40(2), 479-489.

Rojas-Berscia, Luis Miguel \& Corentin Bourdeau. 2018. Optional or syntactic ergativity in Shawi? Distribution and possible origins. Linguistic Discovery 15(1), 50-65.

Rojas-Berscia, Luis Miguel \& Andrey Nikulin. 2018. Proto-Kawapanan, phonological and lexical reconstruction. Ms., Radboud University Nijmegen.

Valenzuela, Pilar. 2011. Contribuciones para la reconstrucción del protocahuapana: Comparación léxica y gramatical de las lenguas jebero y chayahuita [Contributions for the reconstruction of ProtoKawapanana: Lexical and gramatical comparison of the Shiwilu and Shawi languages]. In Willem F. H. Adelaar, Pilar Valenzuela Bismarck \& Roberto Zariquiey Biondi (eds.), Estudios sobre lenguas andinas y amazónicas. Homenaje a Rodolfo Cerrón-Palomino [Studies on Andean and Amazonian languages: Tribute to Rodolfo Cerrón-Palomino], 271-304. Lima: Fondo Editorial Pontificia Universidad Católica del Perú.

Valenzuela, Pilar. 2015. ¿Qué tan "amazónicas” son las lenguas kawapana? Contacto con las lenguas centroandinas y elementos para un área lingüística intermedia [How 'Amazonian' are Kawapanan Languages? Contact with central-Andean languages and elements for an intermediary linguistic area]. Lexis (Peru) 39(1), 5-56.

Valenzuela, Pilar \& Carlos Gussenhoven. 2013. Shiwilu (Jebero). Journal of the International Phonetic Association 43(1), 97-106. 